\title{
Martin Hartmann (1851-1918): A German Orientalist and His Discourse on the Young Turks'
}

Remzi AvcI

\begin{abstract}
German orientalism, which had started out in the context of theological studies and had then evolved into a philological discipline, finally experienced a cultural and social turn. In this development Martin Hartmann (1851-1918) played an important role challenging the tradition of classical philology in the late 19th century and making the living Orient a part of German orientalism. Having worked on different subjects, from Berber folk tales to the Arabic press and Arabic studies, he came to focus more and more on political, cultural and literary studies related to the Islamic world and the Ottoman Empire. Thus, it is not surprising that the Young Turks became important topic for him. His close relationship with the Ottoman intelligentsia and his own observations and impressions of Istanbul enabled him to follow their rise very closely. This article consists of two parts. The first part examines how Hartmann represents the thought of the Young Turks in the context of Ottoman modernisation, proceeding from his early texts to his later works and letters. The second part considers the intellectual background, which accounts for the changes in his approach to the Young Turks.

Key words: Martin Hartmann, Young Turks, Modernization, Ottoman Empire
\end{abstract}

\footnotetext{
${ }^{1}$ This paper is extracted from my PhD Thesis titled: Alman Oryantalizmi: Carl Heinrich Becker ve Martin Hartmann Örneğinde Osmanlı Toplum ve Siyaset Söylemi, Mardin Artuklu Üniversitesi, 2018.

${ }^{2}$ Dr. Öğr. Üyesi, Mardin Artuklu Üniversitesi Tarih Bölümü, remzavci@gmail.com, ORCID No: https://orcid.org/00oo0002-8539-9203.
} 


\title{
Martin Hartmann (1851-1918): Bir Alman Oryantalist ve Jön Türk Söylemi
}

\begin{abstract}
Öz:Teolojiyi merkeze alarak başlayan Alman oryantalizmi, zaman içeresinde filolojik bir disipline daha sonra da kültürel ve sosyal çalışmalara dönüşen bir süreç yaşamıştır. 19. yüzyılın sonlarında klasik filoloji geleneğine itiraz eden ve yaşayan Doğu'yu Alman oryantalizminin bir parçası haline getiren Martin Hartmann (1851-1918) bu değişimin inşasında önemli bir rol oynamıștır. Berberi halk masallarından Arap basını ve Arap dili gibi farklı konular üzerinde çalışan Hartmann, zamanla İslam dünyası ve Osmanlı Devleti ile ilgili siyasi kültürel ve edebi çalışmalara ağırlık vermiştir. Bu bağlamda, Jön Türkler onun yazınının önemli bir parçası haline gelmiştir. Osmanlı entelektüelleri ile yakın ilişkisi, kendi kişisel İstanbul gözlem ve izlenimleri, Hartmann'ın Jön Türkleri çok yakından takip etmesine imkân vermiştir.

Bu çalışma ilk olarak ilk yazılarından son eserlerine ve mektuplarına kadar Hartmann'ın Jön Türk düşüncesini Osmanlı modernleşmesi bağlamında nasıl ele aldığını incelemektedir. Íkinci olarak da onun Jön Türkler algısındaki değişimlerin entelektüel arka planını göstermektedir.
\end{abstract}

Anahtar Kelimeler: Martin Hartmann, Jön Türkler, Modernleşme, Osmanlı Devleti

\section{Introduction}

Having started out in the context of theological studies, German orientalism evolved into a philological discipline. The political discovery of the Orient by the Germans paved the way for yet another, social-cultural turn, which led to a heightened interest in anthropology, ethnology and political sciences. In the transition from theology to philology, the German Arabist Hans Leberecht Fleischer (1801-1888) played a pioneering role. His student Martin Hartmann (1851-1918) went one step further, making the modern Orient a part of German orientalism (Hanisch 2000: 15) As one of the most important scholars in the late 19th and early 20th century Hartmann incorporated sociology and cultural studies into his courses and writings, in opposition to the classical philological tradition. Besides being a scholar, he was also well known for his political writings on the Islamic-Arab World and the Ottoman Empire. There are many studies on Hartmann's biography and on his methodology (Fück 1955; Haarmann, 1974; Hanisch 1992). By contrast, his approach on the Young Turks has received less attention. There are two important studies that deal with the political aspect, an article by Martin Kramer (Kramer 1989: 63-86) and a book by Suzanne Marchand (Marchand 2009). Kramer has offered an analysis of Hartmann's views on Arab nationalism whereas Marchand has situated him in the context of German Orientalism. Yet much remains to be done. The present 
article investigates how Hartmann represents the thought of the Young Turks in his writings in the context of the Ottoman modernisation. It is divided into four parts: The first part offers a brief biography of Hartmann. The second part analyses how Hartmann regards the attempts of the Young Turks to build a modern state. The third part focuses on his views about the Young Turks and demonstrates how they were gradually transformed. The fourth part focuses on currents of political thought in the late Ottoman period as they were seen by Hartmann.

\section{A Brief Biography of Martin Hartmann}

Hartmann was born in 1851 in Breslau as the son of a Protestant preacher. He served in the Franco-Prussian War of $1870 / 1871$ as a religious official (Marchand 2009: XVII-XVIII). Having abandoned theological education, he studied with Fleischer in the department of oriental languages and received his doctorate in Leipzig in the year 1874 with a dissertation about the pluriliteral form in Semitic languages (Hartmann, 1875). After his doctorate, Hartmann stayed a year in Edirne (Ottoman city) as a private tutor and then, in 1876, he started to work as a dragoman in the German Consulate in Istanbul. During this time, he gained his practical knowledge of the Ottoman language (Hanisch 2000: XVIII; Fück, 1955: 269). He then moved to Beirut where he served in the same function until 1887. This assignment was his first experience in diplomacy. His years in Beirut gave him an opportunity to deepen his studies about Arabic dialects, literature and social-political movements in the Arab world (Marchand, 2009: 356; Hanisch, 1992: 17). Hartmann's "pocket-sized phrase book" Arabischer Sprachführer für Reisende-Konversations-Wörterbuch emerged as a result of his experiences in Beirut. This book, which contained the indigenous languages of the region of Syria and facilitated the everyday life of German travellers and merchants, is still a "guiding" work, even in the present day (Kramer 1989: 64; Fück 1955: 269). In 1887, he left the Ministry of Foreign Affairs and started to work as an Arabic teacher at Seminar für Orientalische Sprachen (SOS), (the Seminar for Oriental Languages) in Berlin (Hanisch 2000: XVIII;Mangold 2004: 240-242; Fück 1955: 269). In addition to teaching Arabic, Hartmann gave lectures on anthropological and socio-cultural topics that concerned the Muslim peoples of Asia (Hartmann 1912: III).

He made several expeditions into Ottoman territory and the Far East. In 1902 and 1903, he went to Turkestan. The provincial governor gave him an official permit for his expedition. With this document, he could not only move more freely but also transport across the borders the scientific collections and materials that he gathered during his journey. Thanks to these experiences, Hartmann became an important expert on Turkestan at the German Foreign Office (Mark 2012: 361). In September 1912, he founded the Deutsche Gesellschaft für Islamkunde (German Society for Islamic Studies) with some orientalists who opposed the German philological tradition. Then Hartmann began to publish, 
with Georg Kampffmeyer, Die Welt des Islam, an academic journal on Islam and the Muslim world (Heine 2002: 175-179; Haarmann 1974: 62). In his early works, Hartmann wrote in the context of classical German orientalism, from Berber folk tales to the Arabic press. In time, he started to focus his studies on the Islamic world and the Ottoman State. Hartmann left very important works (including books) on a broad range of topics, from Ottoman literature to culture and art, as well as books (and articles) on Islamic history, literature, culture, religion and so on.

\section{The Young Turks and Modern State Attempts}

Political, cultural and military relations with Germany enabled the transfer of knowledge between the Ottoman Empire and Germany. Thus, it is not surprising that the Young Turks played an important role in the Ottoman discourse of Hartmann. This part of the study examines how Hartmann perceived the attempts of the Young Turks to create a modern state, against the backdrop of sociological and political changes in the Ottoman Empire.

Hartmann believes that the Turks had an exceptional position in the theory and practice of modernisation in the Islamic World. According to him, one of the most important dynamics that kept Ottoman modernisation struggles/movements alive was sending students to Europe. When these young people returned home, they tried to transform the Ottoman society in a European spirit. However, he claims that they succeeded in this only partially (Hartmann 1916a: 97). Hartmann is not yet convinced that a great social and political change could be achieved in the Ottoman Empire by a handful of proWestern intellectuals.

When the notion of a reform after the European model emerged, major debates took place among intellectuals and especially in the bureaucracy of the Ottoman Empire, which revolved around two models, "absolute palace rule" and "the modern-constitutional state." For Hartmann, however, it was rather a conflict between Orient and Occident and in particular between Istanbul and Thessaloniki. While he considers Istanbul the centre of the traditionalists, he regards Thessaloniki as the headquarters of the reformists, the intellectual capital of the Young Turks and the birthplace of the idea of modern Ottoman state. His approach can be seen very clearly in the following statement: "The administration of Asia is in Istanbul. It has become very clear that Istanbul is a real Asian city." (Hartmann 1909a: 122; also see Hartmann 1910a: 8-9). Hartmann thinks that "the confusion of Turkish blood in Thessaloniki with Slavic and Jewish blood" gave them "superiority" as regards modern thinking and inherently an opportunity and capability to build a constitutional state (Hartmann 1910a: 8-9), a statement that reveals him to be a racist. From him the Turks and other oriental nations are unable to produce modern ideas. For this to happen a fundamental prerequisite is the mixture of the blood of the Turks of that of Europeans. In this context, he claims that the traditionalists in Istanbul 
who were politically opposed to the Young Turks and adhered very closely to the sultan's absolutism committed massacres, by declaring their opponents as "the enemies of Allah and His Messenger" (Hartmann 1909b: III- IV). He regards traditionalists as a clique of "fanatic politicians and Muslim preachers" (Hartmann 1913: VIII-IX) and considers them the biggest obstacle to establishing a modern state.

The First Constitutional Monarchy (I. Meşrutiyet) had been established in 1876 and had been suspended by Abdülhamid II in 1878. The debates on Ottoman modernization occupy a large part in his texts. According to him, the re-establishment of the constitutional monarchy (II. Meşrutiyet) on July 23, 1908 was a victory of the intellectual mind (Hartmann 1909c: 39; Hartmann 1909a: 121122; Hartmann 1918: 5). In this new era, fierce struggles took place between Abdülhamid II and the reformers. Therefore, Hartmann supposes that this revolution was not a customary Turkish military coup (Hartmann 1909c: 39; Hartmann 1909a: 121-122; Hartmann 1918a: 5). Despite all disagreements between the various groups, it was an important political success, which should not be underestimated. Hartmann considers this development in 1908 as a revolution rather than a military coup. He did not consider the regime of Abdülhamid II to be in any way justified. Therefore, any movement that seeks to overthrow the sultan would automatically be legitimate.

Hartmann thinks that the military circles in the Ottoman Empire were the carriers of the reform processes and that "their enormous struggles" made this transformation possible. This means that from his point of view that these circles "wanted to move towards a calm and peaceful development" (Hartmann 1911: 1). However, he claims that the comparison of this success with the French Revolution is quite a false analogy because the latter movement was a battle of French People against stupidity (Hartmann 1910a: VII). What he means here is that the Second Constitutional Monarchy was not the result of demands and arduous struggles of the absolute majority of the Ottoman people but was declared by a group belonging to the military and intellectual milieu. From this it can be concluded that Hartmann could not decide exactly how to evaluate this political development. He seems to be confused in his judgements. On the one hand, he regards it as the pioneer of change, on the other hand, he criticizes very severely that it does not have any social basis in the Ottoman society.

Hartmann supposes that Ottoman modernization cannot be realized only by the struggles of the Young Turks. Accordingly, he calls on the "Ottoman people standing on the shores of the rebellion" to internalise ideas of the modern state and to participate in the European cultural world through radical change;

O Turks! Listen to your friends' words. Work tirelessly with your physical power by throwing away your load. Be a part of the Western civilization. Fight for your economic power by entering into 
a union with western nations. Be humble... be unpretentious. So you will be of great value (Hartmann 1910a: VII-VIII).

In this quotation Hartmann criticizes the pride of the Turks, which according to him was based on a romanticised past. He expects from them that they renounce their customary attitudes and face reality because he considers this Turkish national romanticism to the biggest obstacle to Europeanization.

Consequently, he suggests that all these struggles for modernisation could not end the fight between absolutism and movements in favour of a modern constitutional state. The incident of 31 March (31 Mart Vakası), an insurrection in Istanbul by different opponents of the regime of the Young Turks, was a concrete example for this permanent conflict, and this was the one important reason for the dethronement of Abdülhamid II. According to him, this uprising of "the defeated police and theocratic state" in April 13, 1909, which was put down by the Young Turks, was a victory of "enthusiasm, loyalty and intellectuality" (Hartmann 1909b: III). One might think that after the suppression of the March 31 incident, Hartmann gradually began to be convinced about the success of the Young Turks. However, it is quite clear that his analysis in this issue runs constantly into a contradiction in different texts.

Hartmann believes that the political gains of the constitutional monarchy were in danger of being lost again and that the risks of returning to the previous system had not been eliminated. The most important reason, according to him, was that during his long rule, Abdülhamid II had disabled the state mechanism by giving excessive support to certain groups in the Ottoman palace. These were very uncompromising in their opposition to the new rulers and still the biggest obstacle to their plans to build "a regular modern regime" in the whole country (Hartmann 1912:147). In his different writings, Hartmann asks why this class was so opposed to reforms. The main problem was that they perceived the Young Turks as a disaster for the Muslims. The measures that they fought against were especially the recruitment of non-Muslims for the Ottoman army in July 1909 and the recognition of new rights for women (Hartmann 1909a: 127). Their most important commonality was "their adherence to pan-Islamic thought, at the same time their continuing loyalty to Abdülhamid II's state policies", even though he had been deposed (Hartmann 1916a: 149).

\section{Young Turks as a Disappointment}

Hartmann's writings can be divided into two groups: those written before and those written after the dethronement of Abdülhamid II. In the earlier phase, he puts great emphasis on the struggles of the Young Turks against fanatic groups. He was very hopeful that the Young Turks would soon remove the Sharia law from the state apparatus when they came to power. However, after the overthrow of Abdülhamid II, these high hopes suddenly gave way to frustration. In a letter to his close friend Johannes Heinrich Mordtmann, he 
states: "The Young Turks are completely unsuccessful", which demonstrates his disappointment very clearly (DMG Yi 116 I M 239 1909). Then, he began to believe that the new age, which he had welcomed with enthusiasm, brought instead more problems in the domestic and foreign policies of Ottoman Empire (Hartmann 1918b: 225; Hartmann 1909a: 121). Hartmann finds it hard to accept that the Second Constitutional Monarchy, which he regards as a tremendous political success, did not convert the Ottoman society. His observations during his time in Istanbul, which he put on paper in his Unpolitische Briefe aus der Türkei, shaped and influenced his depictions of the Ottoman people. He suggests that in order to reconstruct their state the Turks should take the Bulgarians as a guiding model, who "fought with a great determination for the development of their country" (Hartmann 1910a: 34, 197). However, as stated by him, the Young Turks showed a marked tendency to capitulate easily to the old habits (Hartmann 1911: 1) because, they forgot all of a sudden their pledge of "equality, fraternity and freedom" (Hartmann 1912: 122) and began to resort to violence just like Abdülhamid II. In Hartmann's view, they also did not seek to improve the living conditions of the Ottoman society. His most serious criticism of them is that, despite their claims about the modern and secular state, they did not struggle to "destroy the caliphate" and dismantle the power of Islam. Furthermore, Hartmann claims that some intellectuals, who were capable of building a state in a European spirit, were removed from the power by a small clique within the Young Turks (Hartmann 1913a: XXIV-IX). But Hartmann does not provide information about who these people were.

Hartmann suggests that due to their irresponsible behaviour and arrogant attitudes the political reaction against the Young Turks increased steadily in Ottoman society. According to him, the Young Turks, who wanted to prevent the establishment of a rival political party, betrayed the European spirit, which was the source of their ideology. There was a great expectation in Europe that the new era would create a modern Turkish nation with various "kinds of people". However, what really happened was the "emergence of a kind of miserable Istanbul efendis", who were depicted by Hartmann as "lying, hypocritical and lazy" (Hartmann 1910a: 32). This is for him an exact proof that the Ottoman modernization had failed.

Hartmann's frequent and ardent criticism of the Young Turks in his Reisebriefe aus Syrien disturbed the German Foreign Office. Consequently, a report was written on his book by the ministry. The report claimed that Hartmann was highly biased and prejudiced against the Turks. Furthermore, his depiction of the Young Turks as "dictators of Istanbul" was criticized by the German Foreign Office, which claims that Hartmann considered the development in Istanbul from the "point of view of a provincial Syrian" (PA AA Konstantinopel 417). This report was written in 1913, when the relationship between Germany and the Ottoman Empire was very close. One can conclude that the German Foreign Office feared that Hartmann's book might endanger 
the close bilateral relationship between the two states because it humiliated the Turks.

\section{Ottoman Political Thought and the Young Turks}

In his writings, Hartmann frequently discusses modern intellectual movements, which marked the last period of the Ottoman Empire. He emphasises that the Young Turks offered two ideological recipes for saving the state from collapse. These were pan-Ottomanism and pan-Turkism. PanOttomanism is defined by Kayalı as "the secular state ideology that called for a multiethnic and multireligious empire in which political equality and representative government would foster an imperial allegiance" (Kayalı 1997: 15). There are historical, political and social reasons for its development. Crucial stages were the Tanzimat period when the discourse about the modern state emerged, the First and Second Constitutional Monarchy, and the regime of the Young Turk who transformed it into a state policy. The Young Turks "hoped that religious and ethnic differences would be superseded by a broader Ottoman identity" (Kayalı 1997: 82) Hartmann believes that the idea of such an identity emerged by necessity. According to him, the Young Turks realized that it was no longer possible for seven million Turks to rule seventeen million non-Turkish subjects. They attempted then to build a political Ottoman identity. He formulates these changes as follows: "The Turks themselves are aware of this de facto situation and this (problem) was solved by creating a Scheinvolk (a fictional people), by building an Ottoman identity... and also an Ottoman citizenship" (Hartmann 1909c: 34). One must put together like a puzzle the views on this topic from Hartmann's writings, which date to different periods. Otherwise, it is very difficult to analyse what he understood by the terms of pan-Ottomanism. For instance, in a text from 1913, he suggests that the idea of pan-Ottomanism in the minds of the Young Turks had practically the same connotation as Turkish nationalism (Hartmann 1913a: VII, 66). With a very similar approach in 1914, he claims that pan-Ottomanism was invented in order to soften pan-Turkism (Hartmann 1914: 598), which emerged in the middle of the 19th century especially in the writings of intellectuals who considered the uniting all Turkic people as a recipe for the collapse of the Ottoman Empire (Landau 1974: 193). In 1916, he emphasizes, this time more strongly Ottoman identity and describes pan-Ottomanism as an ambiguous Osmanentum identity (Osmanlılık, being Ottoman) (Hartmann 1916a: 150). Here he considers the ideology of pan-Ottomanism to be identical with the idea of Ottoman identity. As can be seen, his definitions vary considerably. It can be said that these depictions took shape according to the political conditions of the Ottoman state and his relationship with ottoman intellectuals.

Hartmann believes that in reality pan-Ottomanism did not achieve his goal to keep the Ottoman society together. Even though non-Muslim Ottoman subjects gained the right of representation through modernisation movements, they were more inclined to break away from the state, instead of being a part of 
it. (Hartmann 1910b: 72). Hartmann claims that the nationalist rhetoric of the Young Turks and their political practices paved the way for this rupture. For instance, the imposition of Turkish as a teaching language triggered the disengagement of non-Turkish citizens from the government. This policy had only one function, to consolidate the power of the Turks as a ruling group over the whole country and would never be accepted by other Ottoman peoples. (Hartmann 1909c: 47-48).

As mentioned above, Hartmann stresses that at the beginning, the Young Turks offered a political program in which all nations were regarded as equal citizens. However, according to him, they did not implement this program but turned it into a nationalist discourse. He tries to describe this change as follows:

Eventually, the Turks discovered a language that belongs to them. Because, there is something new that promises a lot. This is only possible by creating a great philosophy with a true national language and literature. Only in this way, Turkishness can play a permanent political role (Hartmann 1914: 598).

The defeat of the Ottoman Empire in the Balkan Wars (1912-13) led to the expulsion of the Ottomans from the greater part of their remaining territories in Europe. The separation of non-Muslim populations from the state at the end of this war and the emergence of nationalist movements in the Arab areas forced the Young Turks to make a paradigm shift in politics from pan-Ottomanism towards more centralization.

The terms pan-Turkism and pan-Turanism are used in Hartmann's texts in quite a confused way. Hartmann considers pan-Turanism to be diametrically opposed to pan-Islamism and claims that Turan was not only a geographical but also a cultural term. Its aim was to create "in the future a big Turkish nation, far from all foreign influences" (Hartmann 1916a: 150). In another text Hartmann defines pan-Turanism as follows:

The tendency towards nationalism is especially a provocative rejection against internationalism and European thought... This tendency which finds its power in the word "Turan" is related to a rich ideological thought. It is an idea that sees Central Asia as the cradle of the Turkic peoples and as the spiritual and moral homeland for Ottomans. In this context, Turan should involve more: All countries, in which Turks live and rule (Hartmann 1916c: 97).

Pan-Turkism harks back to the mythological term Turan, which denotes the territory from central Asia to Turkestan. Hartmann describes pan-Turkism as an attempt to Turkify all peoples under a strong national Turkish government (Hartmann 1913a: VII). Hartmann's definition of pan-Turkism as "Turkification of 
all peoples and states (Türkisierung aller Völker und Länder)" is quite complicated. It is not clear from the text whether he refers only to Turkish peoples who live in different geographical regions or to the inhabitants of the Ottoman Empire. This ambiguity may well be due to his highly emotional and idiosyncratic writing style. However, it seems to be the case that he does not regard pan-Turanism and pan-Turkism as two identical terms. While he aligns pan-Turkism with anti-western political sentiment, pan-Turanism has for him rather a cultural significance.

He believes that it is just a utopia to make a new nation or bring the Turkic people together on the basis of Ottoman Turkish, which he depicts as a language with neglected content and "exaggerated morphology". He declares that the pan-Turkists failed to understand the motto: "a new language for new nation". Instead of undertaking an in-depth analysis of the Turkic language in order to return it to its essence, they merely criticized Istanbul Turkish and made minor changes in it (Hartmann 1916a: 150). It is very remarkable, how his opinions in this issue changed in the course of time, as seen below.

Hartmann devoted particular attention to Ottoman literature and requested books and magazines from different Ottoman intellectuals. In that regard, he feels quite hopeful about attempts to purify the Ottoman Turkish. In a letter to Necip Asım (Yazıksız) (1861-1935) who was co-founder of the nationalist Turkish Hearths (Türk Ocağı) in 1911, Hartmann states that the purification will bring Turkish language back and he adds "the Turkish nation will develop its social and moral values, as German experiences" (DMG Yi 116 I R 10,1 and R 102 1909). Furthermore, in a letter to Fuat Raif Bey (Köse) (1872-1949), a member of the Turkish Society (Türk Derneği), Hartmann recommends that they should be more active in practice and publish "a dictionary for Turkishization" (DMG Yi 116 I $N 11$ 1909). However, in the following years, he affirms that the struggles for purification remained quite superficial.

According to Hartmann, the Turks who were in decline culturally and politically did not stand on their own feet and could not be a model for other nations, which were uneducated and far away geographically. Therefore, he believes very strongly that the Young Turks would not be able to implement the idea of pan-Turkism (Hartmann 1913a: VII-IX). Therefore, he considers panTurkism to be a "waste of time". In any case, it did not have a significant ideological basis in Anatolia. Thus, this ideology should be set aside and the Young Turks should focus instead on the development of the people in Anatolia (Hartmann 1916d: 255-256) or at least return to a healthy legitimate nationalism. The best way to achieve this aim was to come to an agreement with "Muslim clerics" (Hartmann 1916e: 142). However, Hartmann did not give details about the role of the Muslim clergy and did not explain what he meant by legitimate nationalism. 
Besides pan-Ottomanism and pan-Turkism a third ideology came into existence, Pan-Islamism, which strove to bring together all Moslems regardless of nationality. Its principal proponent was Abdülhamid II who used it for his own political purposes (Karpat 2001: 16). Hartmann suggests that the Young Turks utilized this ideology as a political instrument that was to help them during the Italo-Turkish War of 1911-1912 and the First World War. He claims that, on the one hand, the Young Turks propagated the idea of pan-Ottomanism in their dealings with non-Muslim subjects, whereas, on the other hand, they secretly injected pan-Islamism and the notion of a Caliphate into the Muslim population. Yet on balance, he regards nationalism as their main ideology (Hartmann 1914: 598).

Hartmann divides the Ottoman intellectuals into the following five groups; orthodox-traditionalists, who advocate pan-Islamism, Turanists like Halim Sabit, Ziya Gökalp who want to get rid of religious doctrines, Muslim liberals, the mystics represented by Riza Tevfik, and scientists like Ahmed Muhiddin (Hartmann 1918b: 225-226). Among these, Gökalp had the greatest impact with his writings. He articulates his opinions about him in a letter to German Foreign Office in very positive way;

This man, who does not come to the forefront and does not play a political role, has left a deep impression especially on the young people, not only in capital, but also in the (Ottoman) provinces in a significant part of the population (PA AA Konstantinopel 402).

In the early days of the First World War, Hartmann met with intellectual and the author of Turkish National Anthem Mehmed Âkif (Ersoy) ${ }^{3}$ in Berlin to whom he had been introduced by the orientalist-diplomat Emil Karl Schabinger von Schowingen (1877-1967) (DMG Yi 116 I S 79 1 1914; Kon 2013: 130-37; Kon 2012: 2-8). He describes Âkif as "incompatible with the spirit of the time and representative of Turkish narrow-mindedness". He believed that Âkif was trapped by the classic Ottoman view, which considers "the Turks as ruling class granting freedom to the Ottoman nations" (DMG Yi 116 I S 791 1914). Besides, he also met the Muslim Intellectual Sheikh Salih at Tunûsi. To his mind there is a serious discrepancy between Tunûsi and Âkif at the intellectual level (DMG Yi 116 I $S 791$ 1914). Âkif's description on this relationship at least as unflattering as Hartmann's expressions;

\footnotetext{
3 Mehmed Âkif (Ersoy) 1873-1936), is an intellectual and the author of Turkish National Anthem, also known for his Pan- Islamist views during the last period of the Ottoman Empire and in the early days of the Turkish Republic. He was a well-known personality in the Ottoman and Islamic worlds and wrote for the Journal Sırat-ı Müstakim (since 1912 Sebilürreşad). Mehmed Akif visited Berlin during World War I for propaganda activities (Kon 2012: 2-8)
} 
This famous orientalist talked about general things, in order to hoodwink me like every science trickster. I seemed to listen to him, then I asked him, 'who is the Turkish poet you know best'? He responded without hesitation; 'Fuzuli'. Then he added: 'Now, I have no time to write about him.' What I saw, was that the man could not read Fuzuli, he never understood him in the least! I could not bear it anymore. I said, 'I am not in a position to check the limits of your knowledge.' However, be sure! The Turkish poet you do not know and understand most is Fuzuli'... After two days, the guy came to me and requested from me to teach him the Su Kasidesi (Eulogy of Water) of Fuzuli (Kon 2012: 4)

Hartmann describes his feelings as follows; "Ultimately, the discussion with these kinds of people does not bring any benefit". It is instantly apparent from this expression that there was a personal antipathy between Âkif and Hartmann (Kon 2012: 4).

Hartmann criticised the German Islam policy before the war. However, during the war, he served, like his colleagues Georg Kampffmeyer, Rudolf Tschudi, Oskar Mann, in the Nachrichtenstelle für den Orient (NfO), The Intelligence Bureau for the East in the Turkish department, which was founded by Max von Oppenheim ${ }^{4}$ as a semi-official intelligence and propaganda institution within the German Foreign Office. One of the most important tasks of the NfO was to organize propaganda activities and operations in the Islamic world (Kon 2013: 77-78).

Although Hartmann stayed close to German Oriental policy during the war, he did not completely renounce the idea that Islam could provoke fanaticism in Muslim societies. In the course of the war, Hartmann played a more active role in the Ottoman and Islam policy of the German empire, especially by becoming involved in translation activities. Schabinger von Schowingen translated Hakikat al Cihad, a booklet written by Salih al-Sharif al-Tunisi, from Arabic into German as Die Wahrheit über den Glaubenskrieg (The Truth about the War of Faith), which was published in Berlin (Kon 2013: 127: Attunusi 1915). Hartmann wrote an introduction to this booklet to make jihad understandable for the German public. In this context, one can say that Hartmann's contribution to the war was at an intellectual level. After his previous writing on Islamic and Turkish hatred, it is quite remarkable to see the positive attitude towards the Ottoman-German rapprochement in his more recent texts.

\footnotetext{
${ }^{4}$ Max von Oppenheim (1860-1946) served as German diplomat in the Middle East. Before the Ottoman Empire entered the war, Oppenheim wrote a memorandum in October 1914. It was 136 pages long and entitled Denkschrift betreffend die Revolutionierung der islamischen Gebiete unserer Feinde (Memorandum regarding the revolutionization of the Islamic territories of our enemies). He planned to create Islamist revolts in colonies in European colonies against the Entente Powers (Gossmann 2013: 81-87).
} 


\section{Conclusion}

In conclusion, one could say that according to Hartmann, Ottoman modernisation faced two main problems: the idea of taking Europe as a direct model for the Ottomans, and the Islamic tradition rooted in the society. Hatred of Abdülhamid II made him favourable towards the Young Turks. His negative stance towards Abdülhamid II was quite remarkable in that it contradicted German foreign policy at the time. Hartmann considers the rise to power of the Young Turks as a defeat of absolutism. At the beginning, he was quite hopeful that the Young Turks would implement reforms in the Ottoman Empire. Then, he lost hope and experienced strong disappointment. He criticizes the Young Turks for not having limited the influence of Islam despite their use of modern-state discourses. According to him, the place where movements of modern thought are stuck and locked is the existence of the caliphate. During the First World War he worked in the NfO to mobilize all Muslims under the umbrella of the caliphate in favour of German Orientpolitik. This activity is quite at odds with his previous thought. It can be concluded that Hartmann had to make big concessions from his values for the sake of politics. It is very remarkable to see Hartmann's friendship with nationalist Ottoman intellectuals, despite his intense critique of pan-Turkism. All of this points to the fact that Hartmann, as a scholar, was very intertwined with politics, just as his colleagues were. In other words, the war atmosphere and enthusiasm captivated him, too.

\section{Bibliography}

\section{Archival Documents}

Nachlaß Martin Hartmann, Bibliothek der Deutschen Morganländische Gesellschaft DMG, Halle

From Hartmann to Johannes Heinrich Mordtmann, the letter of 13 December 1909, DMG Yi 116 I M (239),

From Hartmann to Necip Asım, the letter of 2 July 1909, DMG Yi 116 I R $(10,1)$ and $R(10,2)$

From Hartmann to Fuat Raif Bey, the letter of 7 November 1909, DMG Yi 116 I N (11)

From Hartmann to Karl Emil Schabinger von Schowingen, the letter of 4 December 1914, DMG Yi 116 I S $(79,1)$

Politisches Archiv des Auswartigen Amtes, Berlin (PA AA)

The assessment report dated: 29 December 1913, PA AA Konstantinopel 417

From Hartmann to German Foreign Office, the letter of 14 September 1917, PA AA Konstantinopel 402

\section{Published Works}


Shaich Salih Aschscharif Attunusi. (1915). Haqiqat el Cihad: Die Wahrheit über den Glaubenskrieg. (tras. Karl Schabinger von Schowingen). Berlin: Verlag Dietrich Reimer.

Fück, J. (1955). Die arabischen Studien in Europa bis in den Anfang des 20. Jahrhunderts. Leipzig: Otto Harrassowitz Verlag.

Gossmann, L.(2013). The Passion of Max von Oppenheim: Archaeology and Intrigue in the Middle East from Wilhelm II to Hitler. Open Book Publishers.

Haarmann, U. (1974). "Die islamische Moderne bei den Deutschen Orientalisten" . (Ed.), F. Kochwasser, R. Roemer, Araber und Deutsche Begegnungen in einem Jahrtausend. Tübingen-Basel: Horst Erdmann Verlag: 56-91.

Hanisch, L. (2000). Machen Sie doch unseren Islam nicht gar zu schlecht:Der Briefwechsel der Islamwissenschaftler Ignaz Goldziher und Martin Hartmann 1894-1914. Wiesbaden: Harrassowitz Verlag.

.(1992). Islamkunde und Islamwissenschaft: Der Briefwechsel zwischen Carl Heinrich Becker und Martin Hartmann (1900-1918). Leiden: Dokumentatiebureau Islam-Christendom.

Hartmann, M. (1875). Die Pluriliteralbildung in den semitischen Sprachen: mit besonderer Berücksichtigung des Hebräischen, Chaldäischen und Neusyrischen Bildung durch Wiederholung des letzten Radicales am Schluss und des Ersten nach dem Zweiten. Halle an der Saale: Buchdruck des Waisenhauses.

.(1909c)."Der Islam 1908". Mitteilungen des Seminars für

Orientalische Sprachen an der Königlichen Friedrich-Wilhelms-Universität zu Berlin, Jahrgang XII: 33-83.

.(1909b) Der Islam: Geschichte Glaube und Recht. Leipzig:

Haupt Verlag.

.(1909a) “Abdulhamid". Das freie Wort:Frankfurter Halbmonatsschrift für Fortschritt auf allen Gebieten des Geistigen Lebens 9 Jahrgang: 138-148.

.(1910b). “Deutschland und der Islam”. Der Islam Bd. I: 72-

92.

- (1910a). Unpolitische Briefe aus der Türkei. Der islamische Orient: Berichte und Forschungen. Bd. III . Leipzig: Haupt Verlag,.

.(1911). "Wie sieht es in Arabien aus?". Berliner Tageblatt und Handelszeitung Morgen Ausgabe, 40 Jahrgang Nr. 446: 1.

.(1912). Fünf Vorträge über den Islam. Leipzig: Verlag von

Otto Wiegand.

.(1913). Reisebriefe aus Syrien. Berlin: Dietrich Reimer

Verlag.

.(1914). "Islampolitik". Koloniale Rundschau 5, 11/12: 580-

603.

.(1915)."Die weltwirtschaftliche Wirkungen des Heiligen

Krieges”. Weltwirtschaft: Zeitschrift für Weltwirtschaft und 
Weltverkehr.Organ der Deutschen weltwirtschaftlichen Gesellschaft IV. Jahrgang Nr. 10/11: 255-257.

.(1916b). “Türkisch”. Die Welt des Islams, Bd. IV Heft 1/2: 17-

25 .

.(1916c). "Das türkische Kunstempfinden und das Suchen nach einem Stil”. Die Welt des Islams Bd. IV Heft 1/2: 97-99.

Heft 6: 149-153.

.(1916a). "Turanismus". Das neue Deutschland 5. Jahrgang

.(1916d). "Der Aufbau Anatoliens". Deutsche LevanteZeitung: Monatsschrift für $d$. Handel $u$. Verkehr mit $d$. Mittelmeer- u. LevanteLändern 6. Jahrgang Nr. 7: 255-256.

.(1916e). “Ostwestliche Beziehungen”. Der neue Orient: Korrespondenzblatt der Nachrichtenstelle für den Orient III. Jahrgang: 139-142.

.(1918a)."Die Probleme der Islamwelt (I)". Die Islamische Welt:Illustrierte Monatsschrift für Politik Wirtschaft und Kultur Nr. 1: 5-8.

Welt Nr. 2/3: 75-78.

(1918c). “Die Probleme der Islamwelt (II)”. Die Islamische

.(1918b). “Die Probleme der Islamwelt (III)". Die Islamische

Welt:Illustrierte Monatsschrift für Politik, Wirtschaft und Kultur, Nr. 6/7:224228.

Heine, P. (2002). “Die Deutsche Gesellschaft für Islamkunde”. (Ed.), Rainer Brunner, Monika Gronke, Jens P. Laut, Ulrich Rebstock Islamstudien ohne Ende:Festschrift für Werner Ende zum 65. Geburtstag. Würzburg: Ergon Verlag:175-181.

Kayalı, H. (1997). Arabs and Young Turks Ottomanism, Arabism, and Islamism in the Ottoman Empire, 1908-1918. Berkeley ? Los Angeles ? London: University of California Press.

Karpat, K. (2001). The Politicization of Islam: Reconstructing Identity, State, Faith, and Community in the Late Ottoman State. New York Oxford University Press.

Kon, K. (2013). I. Dünya Savaşı'nda Almanya'nın İslam Stratejisi. İstanbul: Küre Yayınları.

.(2012).“I. Dünya Savaşı'nda Yeni Bilgiler Işığında Mehmed Âkif'in Almanya Seyahati”. Toplumsal Tarih 217: 2-8.

Kramer, M. (1989). “Arabistik and Arabism: The Passions of Martin Hartmann”. Middle Eastern Studies vol. 25 No. 3: 63-86.

Landau, Jacob M. (1974). Radical Politics in Modern Turkey. Leiden: E.J. Brill. 
Mangold, S. (2004). Eine weltbürgerliche Wissenschaft: Die deutsche Orientalistik im 19. Jahrhundert. Stuttgart: Franz Steiner Verlag.

Marchand, S. L. (2009). German Orientalism in the Age of Empire Religion, Race, and Scholarships. New York: Cambridge University Press.

Mark, R. A. (2012). Im Schatten des Great Game: Deutsche Weltpolitik und russischer Imperialismus in Zentralasien 1871-1914. Paderborn-München-WienZürich: Verlag Ferdinand Schöningh. 